JOLANTA M. MARSZALSKA* - WARSZAWA

\title{
INWENTARZE KSIĄG BIBLIOTEKI KARMELITÓW BOSYCH W CZERNEJ, JAKO PRZEJAW SYSTEMATYZACJI ZBIORÓW KLASZTORNYCH W XVIII I XIX WIEKU
}

Zachowane po dzień dzisiejszy Inwentarze bibliotek klasztornych należy traktować jako wyraz stosunków poszczególnych zakonów (a w ich obrębie klasztorów) do książki, gdyż to właśnie na podstawie ich analizy można określić kulturę intelektualną i duchową poszczególnych konwentów, stopień dbałości przełożonych o tworzenie i rozwój biblioteki a zatem i dbałość o pewien poziom umysłowy wspólnoty zakonnej. Jakkolwiek książki w życiu każdego zakonu (klasztoru) odgrywały ogromną rolę począwszy od czysto użytkowej (księgi liturgiczne, chórowe, Pismo Święte), poprzez te dzieła które były ważnym uzupełnieniem zdobywanej wiedzy i samokształcenia, to jednak stosunek do nich w poszczególnych zakonach nie był jednakowy. Często ów fakt był uzależniony od celu, charakteru działalności, funkcji, podstaw materialnych zakonu i jego oddziaływania w środowisku. W klasztorach reguły benedyktyńskiej (benedyktyni, cystersi, kameduli) modlitwa i praca, w tym także lektura książek były istotnym elementem rozwoju wspólnoty i zachowania jej równagi. Stosownie do wskazań ich reguły a także konstytucji zakonnych, mnisi zobowiązani byli znaczną część swego czasu poświęcać lekturze religijnej, obejmującej między innymi czytanie tekstów Pisma Świętego, dzieł Ojców Kościoła, czy ksiąg o tematyce duchowej (ascetyka, mistyka). Podobnie było i w innych zakonach gdzie nacisk na zdobywanie wiedzy był niepodważalny (dominikanie, jezuici, paulini, pijarzy). Księgi bez wątpienia stanowiły niezbędne uzupełnienie w pracy duszpasterskiej, służyły szerzeniu wiary, głoszeniu Słowa Bożego, inspirowały własne poszukiwania duchowe. Nadto trzeba zaznaczyć, że dla tych klasztorów, które prowadziły nowicjaty, szkoły konwentualne, studia partykularne czy generalne - książki stanowiły niezbędne zaplecze naukowe. Nic więc dziwnego, że reguły i konstytucje zakonne, uchwały kapituł generalnych, kładły duży nacisk na organizowanie księgozbiorów w po-

* Jolanta M. Marszalska - dr hab. nauk humanistycznych, adiunkt w Instytucie Nauk Historycznych UKSW w Warszawie. 
szczególnych domach zakonnych, określały zasady gromadzenia, nabywania, konserwacji i udostępniania zakonnikom zbiorów bibliotecznych. Troska o bibliotekę poszczególnych przełożonych zakonnych i klasztornych wyrażała się między innymi w wydawaniu poleceń spisywania jej zbiorów i ujęcia w formę specjalnego inwentarza całości zasobów bibliotecznych.

Historyczne inwentarze bibliotek zakonnych - bardzo często - tych już nieistniejących są potwierdzeniem na istnienie biblioteki w danym klasztorze. Dotyczy to szczególnie tych klasztorów które uległy kasacie a gromadzone przez wieki księgozbiory klasztorne zostały całkowicie rozproszone i nieodwracalnie zniszczone. Zachowane do dnia dzisiejszego inwentarze są również bez wątpienia świadectwem techniki bibliotecznej czasów w których powstawały. A zatem znaczenie inwentarzy bibliotek klasztornych, jako ważnych źródeł historycznych, często jedynych śladów istnienia rozproszonych bibliotek jest zarówno dla kultury intelektualnej i duchowej ogromne. Pozwala bowiem, w sposób, co prawda niedoskonały odtworzyć stan ksiagozbioru, ich zawartość treściową, autorów dzieł, oraz poznać miejsce i oficyny wydawnicze z których księgi pochodziły. Jednocześnie umożliwia poznanie funkcji, jaką książka pełniła na przestrzeni stuleci w życiu poszczególnych społeczności zakonnych. Znaczenie inwentarzy bibliotecznych jako źródła jest niepodważalne, zwłaszcza jeśli mamy do czynienia z zachowanym księgozbiorem klasztornym $\mathrm{i}$ jednocześnie zachowanym inwentarzem bądź inwentarzami jego zbiorów. Analiza księgozbioru dokonana z porównaniem zakonnych inwentarzy bibliotek, daje odpowiedzi na wiele pytań. Pozwala, często z powodu braku innych źródeł na ,uchwycenie” tzw. „polityki bibliotecznej" prowadzonej w danym klasztorze. Pozwala również prześledzić sposoby nabywania ksiag, ich wycofywanie z obiegu oraz to co chyba najistotniejsze - dyscypliny wiedzy, reprezentowanej przez autorów i ich dzieła. A zatem, bez wątpienia konfrontacja zachowanego księgozbioru klasztornego i jego odzwierciedlenia w postaci inwentarza, może stać się doskonałym studium historyczno-poznawczym kultury intelektualnej, duchowej i społecznej klasztoru, który szczęśliwym zbiegiem okoliczności dziejowej zachował do czasów współczesnych dziedzictwo minionych pokoleń zakonników. Według Karola Głombiowskiego Inwentarze czy Katalogi bibliotek klasztornych staja się dla nas ważnymi dokumentami kultury okresu, z którego pochodza [...], pogłębiajq naszq znajomość potrzeb intelektualnych i rozwoju pradów umysłowych epoki ${ }^{1}$.

Jednym z niewielu klasztorów w Małopolsce, który szczęśliwie uniknął kasaty zachowując jednocześnie do czasów współczesnych bogaty księgozbiór jest klasztor Karmelitów Bosych w Czernej. Ufundowany przez Agnieszkę z Tęczyńskich - Firlejowa, klasztor - erem w Czernej został zapewne przez samą fundatorkę jak też i innych ofiarodawców wyposażony w pierwsze podstawowe księgi, które z czasem dały początek bibliotece klasztornej. Podstawę - tak jak zresztą $\mathrm{w}$ innych zakonach stanowiły księgi liturgiczne, w inwentarzu czerneńskim określane jako Libri Ceremonialistae. Księgi liturgiczne stanowiły bowiem niezbędną

${ }^{1}$ K. Głombiowski, Biblioteka Franciszkanów w Nysie w świetle zachowanego Inwentarza z roku 1678, Wrocław 1953, s. 9-10. 
pomoc w sprawowanych nabożeństwach i dlatego też pierwszymi i podstawowymi księgami w klasztorach - w tym także i w Czernej były mszały, psałterze, hymnarze, homiliarze czy officja.

Już w 1634 r. klasztor-erem, otrzymał w darze od klasztoru Karmelitów Bosych w Wiśniczu, dzieła Ludwika de Ponte. Fakt ten został odnotowany w Acta Capituli Conventus Visnicensis Salvatoris Carmelitarum Discalcatorum z $1630 \mathrm{r}$. [...] Aprilis Anno 1634 Cnvocatis Patribus Capituli Propositum fuit opera Ludovici de Ponte septem voluminibus contenta pro nona fundatione S.P.N. Eliae eadem conventui donavi debem conclusum affirum ative omnibus suffragii $[\ldots]^{2}$. Decyzję o przekazaniu dzieł Ludwika de Ponte, wybitnego teologa duchowości, podpisali: o. Hieronim od św. Teresy, przeor w Wiśniczu w latach 1632-1634 i o. Arseniusz od św. Alberta ${ }^{3}$.

Książka w kształtowaniu się duchowym i intelektualnym zakonnika-karmelity bosego, spełniała rolę szczególną. Na wielu zachowanych do dziś portretach karmelitów i karmelitanek bosych minionych wieków, zostały zamieszczone symbole cnót, którymi się odznaczali. Wśród nich obok krzyża, dyscypliny, różańca, czy monstrancji znajdowała się książka jako symbol modlitwy i nauki. Z księga w dłoni przedstawiane były wizerunki św. Teresy Wielkiej, św. Jana od Krzyża, polskich karmelitanek - mistyczki - Teresy Anny Marii od Jezusa (Marianny Marchockiej), Eufrozyny od św. Kazimierza (Heleny Sanguszkówny), czy w końcu fundatorki klasztoru czerneńskiego - Agnieszki z Tęczyńskich Firlejowej

Najważniejszym i niepodważalnym świadectwem stosunku karmelitów bosych do książek, organizacji bibliotek w domach zakonnych była opracowana instrukcja dla bibliotekarza, zamieszczona w zbiorze przepisów zakonnych Instructiones Fratrum Discalceatorum Congregationis S. Eliae Ordinis BVM de Monte

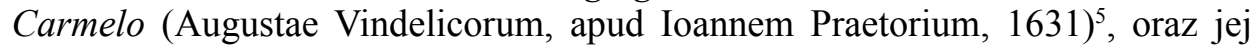
uzupełnienie wydane ponownie drukiem w 1636 r. w Wenecji. Egzemplarz ten jest przechowywany obecnie w klasztorze czerneńskim. Organizacja początków biblioteki klasztornej w Czernej, została uformowana przez konstytucje zakonne, które jasno określały nie tylko cel jej powstania, ale także rolę jaką miała spełniać w strukturze całego zakonu. Ponieważ klasztor karmelitów bosych w Czernej był w założeniu swym eremem, dlatego też pierwsze księgi, które zaczęto gromadzić w bibliotece miały charakter zdecydowanie ascetyczno-mistyczny, mimo, że ,kierunek" gromadzenia książek w bibliotece karmelitów bosych nie był określony dodatkowymi szczegółowymi przepisami. Konstytucje zakonne wyraźnie naka-

\footnotetext{
${ }^{2}$ Archiwum Prowincji Karmelitów Bosych w Czernej (dalej AAP), Archiwum Klasztoru w Wiśniczu (dalej AKWI), sygn. 1, s. 16.

${ }^{3}$ AAP, AKWI, sygn. 1, s. 16; B. J. Wanat, Zakon Karmelitów Bosych w Polsce. Klasztory Karmelitów i Karmelitanek Bosych 1605-1675, Kraków 1979, s. 371.

${ }^{4}$ Portrety wymienionych osób znajdują się w klasztorze czerneński, gdzie atrybut książki jest obok atrybutów świętości życia wyeksponowany przez twórców wspomnianych portretów.

5 J. Długosz, Biblioteka Klasztoru Karmelitów Bosych w Wiśniczu (1630-1649), ABMK, 13 (1966) s. 92; W wydanej Instrukcji s. 143-146, poświęcone zostały bibliotece, zaś zachowany w archiwum czerneńskim oryginał druku z 1631 r. posiada proweniencje klasztoru Karmelitów Bosych pw. Niepokalanego Poczęcia w Krakowie.
} 
zywały przestrzeganie zasady ubóstwa w gromadzeniu książek, co zresztą w porównaniu do księgozbiorów zakonów innych reguł jest mocno widoczne, szczególnie jeśli chodzi o oprawę nabywanych dzieł, która bez wątpienia była w dużym stopniu wyznacznikiem zamożności nabywającego ${ }^{6}$. Z czasem kierunek gromadzenia ksiąg karmelitów bosych w eremie czerneńskim zbliżony zresztą w swej treści do księgozbiorów zakonów innych reguł, wyznaczały dzieła z zakresu biblistyki, patrologii, teologii moralnej, kaznodziejstwa czy nauk wyzwolonych. Doskonałym odzwierciedleniem zasobności biblioteki karmelitów czerneńskich są zachowane w zbiorach archiwum klasztornego inwentarze ksiag, będące nieocenionym źródłem do poznania umysłowości i zapotrzebowania intelektualno-duchowego zakonników.

Najstarszy i zarazem najcenniejszy spośród zachowanych inwentarzy-katalogów ksiagg, przechowywanych w archiwum czerneńskim to Cathalogus Librorum Bibliothecae Conventus Eremitici Sancti Eliae Prophetae Carmelitarum Discalceatorum Conscriptus sub A.R.P.N. Gaudentio a Spiritu Sancto protunc Priore. Anno Increatae Sapientiae, in Libro Naturae Humanae Inscriptae 1718, $26 \mathrm{gbris}^{7}$.

Inwentarz o wymiarach $31 \times 20 \mathrm{~cm}$ został sporządzony za pierwszego przeoratu o. Gaudentego od Ducha Świętego (Zacherli) (1718-1721) ${ }^{8}$ i obok spisu ksiag bibioteki był typowym inwentarzem majątku ruchomego kościoła klasztornego, w którym od karty 43 do karty 68, a zatem do końca inwentarza, spisano już między innymi naczynia i szaty liturgiczne, antepedia, baldachimy, obrazy będące na wyposażeniu kościoła klasztornego jak i znajdujące się w zakrystii oraz w chórze zakonnym. Zasadniczo jednak, był to inwentarz biblioteki klasztornej sporządzony $\mathrm{w}$ formie tabelarycznego zestawienia przez jedną osobę co potwierdza identyczny, staranny dukt pisma. Inwentarz spisano w całości czarnym atramentem, oprawę zaś stanowi tektura, oklejona szarym płótnem.

Zgromadzone $\mathrm{w}$ bibliotece klasztornej księgi zostały ujęte $\mathrm{w}$ inwentarzu z 1718 r. w 17 działach. Są to: [1] Sacra Scriptura; [2] Sancti Patres; [3] Commetatores Sacrae Scripturae; [4] Concionatores; [5] Theologii Morales; [6] Controversistae; [7] Canonistae; [8] Ceremonialistae; [9] Ecclsiastici; [10] Spirituales; [11] Historici Sacri; [12] Historici Prophani; [13] Iuridici et Scholastci; [14] Polonici Spirituales; [15] Polonici Concionatores; [16] Polonici, Historici Sacri et Prophani; [17] Iuridici, Medici, Aeconomiae.

Spośród 17 działów tylko trzy osobno ujmowały dzieła autorów polskich tj. Polonici Spirituales; Polonici Concionatores; Polonici, Historici Sacri et Prophani.

${ }^{6}$ AAP, sygn. 7, Acta Capituli Generalis Fratrum Carmelitarum Discalceatorum Congregatonis S. Eliae ab anno 1605 ad annum 1644, s. 30,120. Autorka niniejszego opracowania bada ksieggozbiory reguły mniszej, klasztoru benedyktynów tynieckich i klasztoru cystersów szczyrzyckich, gdzie bardzo wyraźnie widać różnicę między oprawami ksiąg obu tych bibliotek a skromną oprawą ksiąg biblioteki czerneńskiej.Warto nadmienić, że księgi tynieckie czy szczyrzyckie często wbrew regule były własnością opatów komendataryjnych, dysponujących odrębnym majątkiem, umożliwiającym zakup często drogich ksiagg oprawianych na polecenie zakupującego co nie miało miejsca w przypadku karmelitów bosych.

${ }^{7}$ Archiwum Klasztoru w Czernej (dalej AKC), sygn. 69, k. 68.

${ }^{8}$ Wanat, Zakon Karmelitów Bosych w Polsce, s. 331. 
Kary inwentarza bibliotecznego zostały przez spisującego księgi zakonnika podzielone na następujące rubryki: [1] Materia de qua liber; [2] Nomen Authoris; [3] Folium; [4] Nomen Impressionis et locus impressionis; [5] Annus; [6] Exemplar et tomus.

Inwentarz został spisany zasadniczo $\mathrm{w}$ języku łacińskim a w obrębie wyżej wymienionych trzech działów w języku polskim. Całość została sporządzona bardzo staranie. W pierwszej rubryce oznaczonej Materia de qua liber, zostały zapisane tytuły ksiag, często z oczywistych względów w formie skróconej z zachowaniem zaszeregowania alfabetycznego. W drugiej rubryce Nomen Authoris, zostały zapisaneimiona i nazwiska, bądź niekiedy same nazwiska autorów. Przy wielu znich uwzględniono przynależność zakonną autorów, tytuły grzecznościowe, zaś w przypadku zapisywania autorów z zakonu karmelitów bosych, umiszczano również ich predykaty. Trzecia rubryka Folium, służyła do zapisywania formatu bibliograficznego ksiegi; w czwartej Nomen Impressionis et locus impressionis, zapisano miejsce wydania i oficynę wydawniczą; w piątej Annus, rok wydania dzieła, zaś w szóstej Exemplar et tomus, ilość egzemplarzy danego tytułu dzieła, znajdującego się aktualnie w bibliotece. Jednakże ta ostatnia rubryka nie zawsze była konsekwentnie wypełniana.

O wysokim stopniu przygotowania spisującego księgi zakonnika, świadczy również fakt, iż używał on w inwentarzu fachowych terminów bibliotekarskich np.: liber, pars - na oznaczenie części dzieła; tomus, volumen - na oznaczenie tego samego dzieła. Bibliotekarz zakonny zastosował również fachowe skróty: eiusdem (authoris), in eodem (folio), ibidem (loco), apud eundem (typhographum), eodem (anno). Na każdej karcie, bardzo starannym kaligrafowanym pismem zapisany został tytuł (nazwa działu). Poszczególne działy spisujący zakonnik podzielił według alfabetu od litery A do Z, również w obrębie poszczególnych liter alfabetu zastosowany został dalszy szczegółowy podział tytułów dzieł.

Analizując inwentarz, daje się zauważyć, że niekiedy to samo dzieło zostało zapisane w dwóch różnych działach. Najwięcej widocznych niekonsekwencji jest w doborze haseł. Spisujący bowiem inwentarz - zakonnik, brał pod uwagę z reguły nazwisko autora, rzadziej już jego imię, albo pierwszy wyraz tytułu. Innym powodem zaistniałych różnic, była „szczupłość miejsca w rubrykach”, która znacznie utrudniała zachowanie początkowego układu inwentarza. Ponieważ książki napływały do biblioteki w różnym czasie (zakupy, legaty testamentowe, darowizny), tzw. rezerwa miejsca przy poszczególnych grupach alfabetycznych nie zawsze była wystarczająca. Mimo pewnych uchybień czy niekonsekwencji w zapisach, inwentarz biblioteki czerneńskiej z $1718 \mathrm{r}$. bez wątpienia reprezentował wysoki poziom znajomości ówczesnej techniki bibliograficzno-bibliotecznej. Inwentarz, zarówno od strony metodologii jego sporządzenia, jak nade wszystko zawartości treściowej samego księgozbioru jest charakterystyczny dla bibliotek karmelitów bosych z tego okresu9 ${ }^{9}$ Obejmuje on 925 dzieł w ok. 990 woluminach ${ }^{10}$.

${ }^{9}$ Przykładem jest między innymi przechwywany w Archiwum Klasztoru w Czernej jest Cathalogus Librorum Conventus Immaculae Conceptionis B.V.M. F.F. Carmelitarum Discalceatorum, Cracoviae Factus Anno Domini 1702. ANPK, sygn. 7.

${ }^{10}$ J. Długosz, Biblioteka klasztoru karmelitów bosych w Czernej, ABMK, 11 (1965) s. 110. 
Analiza treściowa inwentarza umożliwia poznanie świata kultury umysłowej, zainteresowań intelektualnych i duchowych karmelitów bosych w Czernej, którzy zgromadzili z niemałym trudem znaczny księgozbiór. Krąg użytkowniów biblioteki czerneńskiej był oczywisty. Byli nimi wyłącznie zakonnicy - eremici. Z księgozbioru klasztornego korzystali przede wszystkim zakonnicy odpowiedzialni za formację zakonną, kaznodzieje zakonni, penitencjarze. Nadto księgi - szczególnie te duchowe były podstawą do samodoskonalenia się zakonników we wszelkich cnotach poprzez poznawanie między innymi dzieł autorów karmelitańskich. Dowodem jest między innymi fakt zaczytania pism św. Teresy od Jezusa, św. Jana od Krzyża, Tomasza od Jezusa czy Cyryla od św. Franciszka.

Zachowany inwentarz biblioteki karmelitów bosych w Czernej z 1718 r. jest doskonałym przykładem dbałości o księgi klasztorne, stanowiąc kapitalne źródło poznawcze do badań nad kulturą książki w środowisku karmelitańskim eremu czerneńskiego od momentu jego fundacji do początku XVIII w.

Kolejne zachowane inwentarze ksiag pochodzą już z XIX w. i chociaż klasztor karmelitów bosych w Czernej nigdy nie uległ kasacie, zachowując ciagłość dziejów a tym samym ciagłość ,samej biblioteki”, to jednak położony w obrębie zaboru austriackiego, klasztor jak i jego majątek nieruchomy i ruchomy z polecenia władz zaborczych podlegał wielokrotnemu spisowi. W 1797 r. po kasacie klasztoru św. św. Michała i Józefa w Krakowie, częśc tamtejszego zgromadzenia przeprowadziła się do eremu czerneńskiego, przywożąc ze sobą niewielkie fragmenty tamtejszej biblioteki [...] od tego czasu ćwiczenia eremickie skończyly się. Z powodu rosporzadzeń cesarskich erem nie miat juz racji bytu [...] klauzura wielka papieska zostata zniesiona w 1805 r. aktem nr 569 z dnia 13 VII 1805 r. konsystorz biskupi pozwolit dopuścić wiernych obojga ptci do uczestnictwa w nabożenstwach $w$ kościele, dotychczas nieprzerwanie stużacym tylko pustelnikom karmelitańskim. Prawnej i formalnej zmiany eremu na konwent dokonao na Kapitule Generalnej w Rzymie w $1807 r^{11}$ Klasztor prowadząc od tego momentu parafię zdołał tym samym uchronić się od kasaty. Jednocześnie efektem kolejnych wizytacji klasztornych, mających na celu podniesienie ducha zakonnego i karności wśród zakonników, było przeprowadzenie stopniowej reformy życia wewnątrz klasztoru czerneńskiego. Był to kolejny ważny krok mający na celu uchronienie klasztoru przed kasatą ze strony władz austriackich. Na prośbę o. Elizeusza od Niepokalanego Poczęcia NMP, generał zakonu zwrócił się do Stolicy Apostolskiej o pozwolenie na przyłączenie konwentu czerneńskiego do prowincji austriackiej. Na mocy dekretu Kongregacji Biskupów z dnia 13 I 1863 r., papież Pius IX przychylił się do powyższej prośby. Faktycznego przyłączenia klasztoru czerneńskiego do prowincji austriackiej na mocy tego dekretu dokonało dopiero Definitorium Generalne w Rzymie dnia 15 XI $1875 \mathrm{r}^{12}$

W tym czasie na polecenie władz austriackich majątek klasztoru czerneńskiego wielokrotnie podlegał spisowi. Spisem objęte były również książki.

${ }^{11}$ AKC, sygn. 36, Acta Curiae Episcopi Cracoviensi ab A.D. 1797-1953, s. 36; Por. Wanat, Zakon Karmelitów Bosych w Polsce, s. 321.

${ }^{12}$ Wanat, Zakon Karmelitów Bosych w Polsce, s. 324. 
Z 1810 r. pochodzi Cathalogus Librorum qui Reperiuntur In Bibliotheca Carmelitarum Discalceatorum Conventus Czernensis sub titulo S.P.N. Eliae Prophetae, który został dołączony do Inwentarza Klasztoru i Posiadłości Karmelitów Bosych $w$ Czernej z tegoż roku ${ }^{13}$. Inwentarz o wymiarach $37 \times 23 \mathrm{~cm}$ został spisany przez co najmniej dwie różne osoby, o czym świadczy różny dukt pisma, w wielu miejscach niedbały bez zastosowania właściwych reguł wymaganych przy tego typu spisach. Zgromadzone w bibliotece klasztornej księgi, spisujący uszeregował w następujących działach: [1] Patres; [2] Morales; [3] Libri Historici, Religiorum et Vitae SS. Patrum; [4] Spirituales; [5] Concionatores; [6] Philosophii et Theologii; [7] Libri Italici; [8] Libri in Sacristici; [9] Libri in Choro. A zatem w porównaniu do katalogu ksiąg z 1718 r. różnice są bardzo istotne. Zabrakło wydzielenia osobnego działu ujmującego między innymi Pismo Święte i jego komentarze, ksiag z zakresu prawa kościelnego i cywilnego czy sztuk wyzwolonych. Księgi z tak obszernego działu jakim był dział duchowości, spisujący częściowo zakwalifikował do działu Morales, częściowo do działu Spirituales. Katalog z 1810 r. ujmuje księgi w obrębie zaledwie dziewięciu działów - dla porównania, katalog z 1718 r. ujmuje je aż w 17 działach. Nadto księgi ujęte we wspomnianych 9 działach, spisane zostały wyłącznie w układzie tytułów dzieł bez zastosowania kryterium alfabetycznego. Jedynie przy niektórych tytułach spisujący zamieścił imię, bądź nazwisko autora. Brak też jest miejsca i roku wydania a także oficyny wydawniczej. Zachowany został jedynie podział ksiag według formatów. Na pierwszej karcie katalogu spisujący zanotował: Xsiążi łaciński, polskie, niemieckie, francuskie, spisane w $1810 \mathrm{r}$. Nadto uwzględnione zostały księgi będące na wyposażeniu zakrystii kościoła i chóru zakonnego. Nie ulega wattpliwości, iż był to spis sporządzony na polecenie władz gubernialnych, gdzie obok majątku klasztornego, książki jako jeden z elementów tegoż majątku, podlegały również inwentaryzacji. Katalog został sporządzony za przeoratu o. Lamberta od Najświętszego Skramentu (Bugajewicza), sprawującego urząd przeora w klasztorze czerneńskim w latach 1797-1811 ${ }^{14}$.

Z 1816 r. pochodzi kolejny spis ksiag, jest to: Catalogus Librorum qui Reperiuntur In Bibliotheca Carmelitarum Discalceatorum Conventus Czernensis sub Titulo S.P.N. Eliae Prophetae. Podobnie jak i poprzedni, spis ksiag z 1816 r. został również dołączony do Inwentarza Klasztoru i posiadłości oo. Karmelitów Bosych ${ }_{w}$ Czernej z tegoż roku ${ }^{15}$. Inwentarz o wymiarach $37 \times 25 \mathrm{~cm}$ został spisany przez jedną osobę. Również i w tym przypadku widoczny jest duży pośpiech i niedbałość w jego przepisywaniu. Tu z kolei księgi zaszeregowane zostały zaledwie w siedmiu działach: [1] Patres; [2] Morales; [3] Concionatores; [4] Philosophii et Theologii; [5] Libri Italici; [6] Libri Sacristiae; [7] Libri in Choro.

Spisujący księgi klasztorne, podobnie jak i w inwentarzu z 1810 r. całkowicie pominął dział obejmujący Pismo Święte, jego komentarze oraz dział duchowości. Księgi Spirtuales zakwalifikowane zostały do działu Morales oraz Philosophii et Theologii, co świadczyłoby o zupełnym braku wiedzy na temat zawartości po-

\footnotetext{
${ }^{13}$ AKC, sygn. 64, s. 116-132.

${ }^{14}$ Wanat, Zakon Karmelitów Bosych w Polsce, s. 331.

${ }^{15}$ AKC, sygn. 64, s. 136-153.
} 
szczególnych dzieł i ich autorów. W obrębie zaledwie siedmiu działów księgi zostały spisane według tytułów dzieł, bez zastosowania układu alfabetycznego. Przy niektórych tytułach, podane zostało imię, bądź nazwisko autora. W obrębie tzw. działu zachowany został podział ksiag według formatów. Podobnie jak i poprzedni, spis katalogowy ksiag klasztornych z 1816 r. nie nosi znamion opisu fachowego. Pod sporządzonym spisem katalogowym ksiag, zostało zamieszczone imię i nazwisko spisującego: $x$. M. Trawiński mpp A.D. 1816. Fakt ów miał miejsce za przeoratu o. Kandyda od św. Władysława (Piotrowskiego), sprawującego urząd przeorski w latach 1811-1817'16. Warto zaznaczyć, że pierwsza połowa XIX w. to bardzo trudny czas dla klasztoru czerneńskiego, który w 1814 r. stanął w obliczu katastrofy gospodarczej jak i też upadku ducha zakonnego. Rekwizycje i kontrybucje wojskowe po upadku Napoleona, doprowadziły do tego jak zaznaczył o. Kandyd Piotrowski, iż [...] nie pozostało w klasztorze ani źdźbła siana czy stomy, ani ziarna czy to do pożywienia czy do zasiewu. Wojsko zabrało bydto, konie, wozy. Z 24 kmieci pozostało czterech, których klasztor musiat żywić i zaopatrywać $[\ldots]^{17}$. Nadto sam kościół klasztorny wymagał natychmiastowego remontu. Wobec takiej sytuacji trudno się dziwić, że dokonano spisu majątku klasztornego zapewne na prędce, gdyż ówczesny biskup krakowski, Jan Woronicz był mocno niezadowolony z takiego stanu rzeczy obwiniając w dużym stopniu złym stanem klasztoru, przeora Piotrowskiego, postulując Defintorium Prowincjonalnemu, jego zmianę ${ }^{18}$. Jak już zaznaczono oba „katalogi ksiag”, zarówno z 1810 jak i z 1816 r. sporządzone w odstępie zaledwie sześciu lat, zostały dołączone do Inwentarza Klasztoru i Posiadtości oo. Karmelitów Bosych w Czernej, obejmującego lata 1719-1900 i są z nim współoprawne.

Ostatni z XIX wiecznych inwentarzy klasztornych, obejmujących również swoim spisem książki to: Inwentarz Klasztor Karmelitów Bosych na Czernej wraz z Posiadłościami do tegoż Klasztoru należacych z roku 186519. Został on sporządzony za przeoratu o. Juliana od Trójcy Świętej (Antoni Kozubski), i był zapewne wynikiem przeprowadzonej wizytacji klasztoru na polecenie Definitorium Generalnego w Rzymie, które zostało wcześniej poinformowane o trudnej sytuacji ekonomicznej i moralnej klasztoru. Sprawowane w tym czasie rządy przeora Kozubskiego pozostawiały wiele o życzenia, gdyż jak odnotowano [...] przeor rezyduje $w$ folwarku w Siedlcu. Do klasztoru przyjeżdza tylko na większe uroczystości. Wszystko czyni z własnej inicjatywy bez porady dyskretów, których nie ma i bez wiedzy kapituly. Kapitut konwenckich nie odprawia, stad rodzi się niezadowolenie zakonników. Życie wspólne nie jest przestrzegane [... $]^{20}$. Był to ostatni spis majątku klasztornego przed przyłączeniem konwentu czerneńskiego w 1875 r. do prowincji austriackiej. Inwentarz o wymiarach $41 \times 26 \mathrm{~cm}$ jest kolejnym typowym spisem obejmującym ruchomości klasztoru i kościoła czerneńskiego, w tym jak

${ }^{16}$ Wanat, Zakon Karmelitów Bosych w Polsce, s. 331.

${ }^{17}$ AKC, sygn. 36, Acta Curiae Episcopi Cracoviensi ab A.D. 1797-1953, s. 39.

${ }^{18}$ Wanat, Zakon Karmelitów Bosych w Polsce, s. 321.

${ }^{19}$ AKC, sygn. 68, k. 33-70v.

${ }^{20}$ AKC, sygn. 23, Liber Susceptorum ac neoprofessorum tam fratrum clericorum quam donatorum ab anno 1823 ad 1872, s. 1-52; Wanat, Zakon Karmelitów Bosych w Polsce, s. 322-323. 
odnotowano [...] opisanie kościoła, budynków i sprzętów kościelnych, opisanie zakrystii, opisanie dóbr, budynków $i$ innych sprzętów, należacych do księży karmelitów z Czernej tj. obrazów w zakrystii, chórze i kaplicy [...] ${ }^{21}$. Inwentarz zosał sporządzony w latach 1864-1865 przez kilka osób o czym świadczy różny dukt pisma w języku polskim i niemieckim. Na karcie 138v zamieszczony został zapis zatwierdzający stan posiadania klasztoru, ujęty w inwentarzu przez władze administracyjne w Krakowie 3 V 1865 r. Stan faktyczny został potwierdzony własnoręcznym podpisem przeora o. Juliana od Trójcy Świętej (Anoniego Kozubskiego), podprzeora klasztoru o. Cyryla Gawrońskiego oraz o. Romeusza o św. Alojzego (Brożka). Na kartach 33-70v, spisujący inwentarz odnotował księgi będące w klasztorze, $\mathrm{z}$ podziałem na książki kościelne tj. będące w posiadaniu zakrystii, wśród których odnotował 6 mszałów drukowanych, z których najstarszy - Missale pro Defunctis, pochodził z 1644 r. i wydany został w Krakowie. Pozostałe książki będące w bibliotece klasztornej zostały spisane w dziale zatytułowanym Ksiqżki na bibliotece znajdujące się. Spisujący księgi nie uwzględnił żadnego kryterium ich podziału. Jedynie przy tytułach (i to nie wszystkich) zostało podane miejsce i rok wydania książki a także ilość egzemplarzy danego tytułu. Jedynie począwszy od karty $62 \mathrm{v}$ odnotowany został podział książek na: książi włoskie, ksiażki hiszpańskie, ksiqżki francuskie, ksiażki niemieckie i ksiażki polskie. Pod spisem na karcie 70v innym już charakterem pisma odnotowano: [...] Uwaga ksiażki powyższe właściwej wartości nie maja, obejmuja li tylko żywota świętych, przeto i cena szacunkowa onychże położona bydź nie mogła, datum Czerna dnia 30 października 1864 r. [... $]^{22}$.

Z powyższych zapisów jasno wynika, że spis książek został tu potraktowany czysto ekonomicznie, sporządzony bez jakiejkolwiek fachowości i skruplatności, która jest wymagana przy sporządzaniu katalogów książek. Inwentarz miał bowiem w pierwszej kolejności wykazanie stanu posiadania majątku ruchomego klasztoru, podania szacunkowej wartości posiadanych sprzętów liturgicznych i innych przedmiotów materialnych do których również zaliczano książki. Uwaga zaś zamieszczona pod tekstem, jakoby książki obejmowały jedynie Żywoty świętych nie jest prawdziwa. Wstępne porównanie ksiag ujętych $\mathrm{w}$ inwentarzach z 1718, 1810, 1816 i w końcu z 865 r. w pełni potwierdza, że były to księgi z różnych dyscyplin wiedzy, pokrywające się z inwentarzem z 1718 r., tyle, że począwszy od inwentarza z 1810 r. aż do ostatniego z 1865 r., spisane zostały niedbale, nie fachowo i bez zastosowania jakiegokolwiek kryterium ułatwiającego korzystanie i pogłębioną analizę księgozbioru.

A zatem jedynym inwentarzem ksiąg biblioteki karmelitów bosych w Czernej sensu stricto jest Cathalogus Librorum Bibliothecae ... z 1718 r.

Z przełomu XIX i XX wieku klasztor czerneński przechowuje w swoim archiwum kilka inwentarzyków ksiąg, $\mathrm{z}$ reguły spisanych przez zakonników w małych zeszytach, sporządzonych specjalnie przez ofiarodawców, legujących swoje prywatne zbiory dla biblioteki czerneńskiej. Są wśród nich również książki w języku

\footnotetext{
${ }^{21}$ AKC, sygn. 68, k. 1.

${ }^{22}$ AKC, sygn. 68, k. 70.
} 
niemieckim, przywiezione do Czernej przez zakonników austriackich w $1875 \mathrm{r}$. z Linzu. Spisane sa one w Inwentarzu-zeszycie o wymiarach $21 \times 17$ Verzeichnis der deutschen Bucher in der Bibliotek zu Czerna ${ }^{23}$. Analogicznie datowany jest kolejny inwentarzyk książek o wymiarach $21 \times 17$ zatytułowany Libri extra Bibliotheca $^{24}$, sporządzony w języku łacińskim i polskim przez o. Jana Chrzciciela od Najświętszego Serca Jezusa (Bouchaud), wieloletniego magistra nowicjatu klasztoru czerneńskiego, sprawującego tę funkcję w latach 1886-1892, 1895-1900 oraz 1903-190925.

Przykładem ksiag legowanych testamentem dla klasztoru w Czernej jest dar księdza Wincentego Smoczyńskiego (1842-1903), wytrawnego bibliofila, od 1879 - proboszcza parafii pod wezwaniem św. Katarzyny z pobliskiego Tęczynka, a od 1901 r. proboszcza parafii pod wezwaniem św. Floriana w Krakowie. Warto zaznaczyć, że kapłan ten w trakcie pobytów poza granicami kraju w latach 1865-1867, będąc w Rzymie, Paryżu a nade wszystko w Antwerpii, Brukseli, Lowanium, pracował $\mathrm{w}$ tamtejszych bibliotekach, co pozwoliło mu z czasem zdobytą wiedzę wykorzystać w swojej pasji biblioflskiej. W 1872 r. za działalność patriotyczną został uwięziony w X Pawilonie Cytadeli warszawskiej i zesłany do Jarosławia nad Wołgą. Był czynnie zaangażowany patriotycznie i duchowo w życie zesłańców z którymi dzielił los skazańca. Po zwolnieniu od 1876 r. był wikariuszem parafii Wszystkich Świętych przy kościele św. Piotra i Pawła, zaś od roku 1878 został notariuszem sądu biskupiego w Krakowie. Rok później objął probostwo w Tęczynku, gdzie włożył wiele wysiłku w odnowienie starego, tęczyńskiego kościoła. W latach 80. i 90. XIX stulecia współpracował z krakowskim Czasem i Kalendarzem Józefa Czecha. Był wytrawnym bibliofilem i kapłanem wzorowych obyczajów, zawsze gorliwy w spełnianiu swych obowiązków ${ }^{26}$. Zgromadzony przez siebie księgozbiór ks. Smoczyński przekazał legatem testamentowym klasztorowi w Czernej. Inwentarz odnotowujący tę darowiznę nosi tytuł Spis ksiażek ofiarowanych przez Przewielebnego Księdza Prałata x. Dr Wincentego Smoczyńskiego, Czci Najgodniejszego Księdza Proboszcza w Tęczynku [przez o. Romualda od św. Eliasza Kućke] ${ }^{27}$ i pochodzi z przełomu XIX i XX wieku. Liczy łącznie 37 kart, zapisanych czarnym atramentem w języku polskim i łacińskim o wymiarach $21 \times 17 \mathrm{~cm}$. Przekazane klasztorowi książki zostały ujęte w dziesięciu następujących działach: [1] Humanitates et Historia Profana et Ecclesiastica; [2] Scientiae (Philosophia); [3] Ius; [4] Theologia dogmatica; [5] Theologia moralis; [6] Acta Sanctorum; [7] Scriptura Sacra; [8] Praedicatia; [9] Spiritualia; [10] Spiritualia (Ascesis). W obrębie każdego działu spisujący księgi ujął je tabelarycznie. A zatem w spisie książek legowanych przez księdza Smoczyńskiego klasztorowi w Czernej, zastosowany został w miarę czytelny podział książek, wyszczególniający 10 działów, w obrębie których książki spisane

${ }^{23}$ AKC, sygn. 69c, kk. 16.

${ }^{24}$ AKC, sygn. 71, kk. 35.

${ }^{25}$ Wanat, Zakon Karmelitów Bosych w Polsce, s. 333.

${ }^{26}$ R. Róg, Wincenty Smoczyński, w: Polski Stownik Biograficzny, t. 39, z. 160, Warszawa 1999, s. 211-214.

${ }^{27}$ AKC, sygn. 70, kk. 37. 
zostały z uwzględnieniem nazwiska autora, tytułu książki, miejsca i roku wydania a także oficyny wydawniczej. Podana została również ilość tomów poszczególnych tytułów. Dar ksiagg księdza Wincentego Smoczyńskiego dla biblioteki czerneńskiej ma charakter szczególny. O przekazaniu swojego cennego zbioru klasztorowi w Czernej, zdecydował fakt między innymi bliskiego sąsiedztwa i przyjaźni łączącej proboszcza w Tęczynku z karmelitami bosymi w Czernej a nade wzystko poprzez osobę św. Rafała Kalinowskiego z którym łączyły go więzy głębokiej przyjaźni i wspólnej tułaczki syberyjskiej. Św. Rafał Kalinowski był również kierownikiem duchowym bratanicy ks. Smoczyńskiego, Zofii Kazimiery Smoczyńskiej, która wychowywała się w Tęczynku pod opieką stryja. Dzięki o. Kalinowskiemu wstapiła do zakonu karmelitanek bosych w Przemyślu, przyjmując imię zakonne Maria Weronika od Najświętszego Oblicza. W latach 19291932 była przeoryszą w przemyskim Karmelu ${ }^{28}$.

Ostatnim inwentarzem ksiag biblioteki karmelitów bosych w Czernej jest Cathalogus Librorum Bibliothecae Conventus Czernensis Carmlitarum Discalceatorum per fr. Andream a Iesu Gdowski conscriptum ${ }^{29}$. Inwentarz o wymiarach $34 \times 21 \mathrm{~cm}$ został sporządzony w języku łacińskim i polskim przez o. Andrzeja od Jezusa (Gdowskiego), przeora klasztoru czerneńskiego w latach 1912-1918 ${ }^{30}$. Wzorując się na Spisie ksiag..., ofiarowanych klasztorowi przez ks. Wincentego Smoczyńskiego, przeor Andrzej od Jezusa (Gdowski) zastosował pewne zmiany dotyczące podziału ksiagg biblioteki czerneńskiej, tworząc dodatkowo nowy dział a mianowicie Patrologię oraz rozdzielając w zapisie księgi ujęte w dziale Historia Profana i Historia Ecclesiastica. Do działu Praedicatio włączył kaznodziejstwo polskie i łacińskie. Sporządzony przez o. Andrzeja Gdowskiego Catalogus Librorum ..., ujmował księgi w 13 działach: [1] Humanitates; [2] Historia Profana; [3] Historia Ecclesiastica; [4] Scientiae; [5] Ius Civiles et Ecclesiastici; [6] Theologia dogmatica; [7] Theologia moralis; [8] Theologia mystica; [9] Acta Sanctorum; [10] Scriptura Sacra; [11] Patres; [12] Praedicatio Polonice et Praedicatio Latinae; [13] Spirituales.

Niestety inwentarz ksiąg został sporządzony bardzo niestarannie, widoczny jest pośpiech w zapisach, co sprawia trudność w jego odczytaniu w wielu miejscach. Całość oprawiona została w utwardzoną okładzinę tekturową, oklejoną szaro-niebieskim papierem, grzbiet inwentarza wzmocniony został szarym płótnem.

Zachowane XVIII i XIX wieczne inwentarze księgozbioru biblioteki czerneńskiej, świadczą o podejmowaniu przez klasztor starań około spisania i uporządkowania książek. Ich wartość jest różna. Bez wattpienia najlepszym i najbardziej fachowym od strony warsztatu jest inwentarz z $1718 \mathrm{r}$. Zostały w nim przejrzyście wyodrębnione działy wiedzy wraz z podaniem opisu wydawniczego książki. Takich informacji nie zawierają już inwentarze z 1810, 1816 czy 1865 r. Od strony techniki sporządzenia i podziału księgozbioru na działy tematyczne, zbliżony jest w swojej konstrukcji do inwentarza z 1718 r., Spis ksiag ofiarowanych klasztorowi czerneńskiemu na przełomie XIX i XX w. przez ks. Wincentego Smoczyńskiego.

\footnotetext{
${ }^{28}$ Cz. Gil, Stownik polskich karmelitanek bosych 1612-1914, Kraków 1999, s. 269.

${ }^{29}$ AKC, sygn. 69b, ss. 130.

${ }^{30}$ Wanat, Zakon Karmelitów Bosych w Polsce, s. 332.
} 


\section{DIE INVENTARVERZEICHNISSE DER BIBLIOTHEK DER BARFÜSSIGEN KARMELITEN ZU CZERNA ALS EIN BEISPIEL FÜR DIE SYSTEMATISIERUNG DER KLOSTERBIBLIOTHEKEN IM 18. UND 19. JAHRHUNDERT}

\section{Zusammenfassung}

Folgende Inventarverzeichnisse der Bibliothek von Czerna aus dem 18. und 19. Jahrhundert sind erhalten: Cathalogus Librorum Bibliothecae Conventus Eremitici Sancti Eliae Prophetae Carmelitarum Discalceatorum sub A.R.P.N. Gaudentio a Spiritu Sancto protunc Priore. Anno Increatae Sapientiae, in Libro Naturae Humanae Inscriptae 1718, 26 gbris, Cathalogus Librorum qui Reperiuntur In Bibliotheca Carmelitarum Discalceatorum Conventus Czernensis sub titulo S.P.N. Eliae Prophetae, : Catalogus Librorum qui Reperiuntur In Bibliotheca Carmelitarum Discalceatorum Conventus Czernensis sub Titulo S.P.N. Eliae Prophetae, beigefügt zum Inventarverzeichnis des Klosters und der Besitztümer der Barfüßigen Karmeliter in Czerna von 1810 (poln.); Catalogus Librorum qui Reperiuntur In Bibliotheca Carmelitarum Discalceatorum Conventus Czernensis sub Titulo S.P.N. Eliae Prophetae von 1816; Inventarverzeichnis des Klosters der Barfüßigen Karmeliten in Czerna zusammen mit den zu diesem Kloster gehörenden Besitztümern aus dem Jahre 1865 (poln.); Verzeichnis der deutschen Bücher in der Bibliothek zu Czerna von 1975 sowie das Verzeichnis der von dem Hochwürdigen Herrn Prälat Dr. Wincenty Smoczyński, Pfarrer in Tęczynek, [durch P. Romuald od św. Eliasza Kućka] gespendeten Bücher von der Wende des 19./20. Jahrhunderts. Diese Bücherverzeichnisse zeugen von den Bemühungen des Klosters, die Bücher zu registrieren und zu ordnen. Das beste und handwerklich am fachmännischsten gestaltete Inventarverzeichnis ist zweifellos das von 1718. Darin wurden die Wissensgebiete übersichtlich voneinander abgegrenzt und auch eine verlegerische Beschreibung der jeweiligen Bücher beigefügt. Solche Informationen enthalten die Verzeichnisse von 1810, 1816 oder 1865 nicht mehr. Hinsichtlich der Technik der Anordnung und Einteilung der Büchersammlung in Themengebiete ähnelt in seiner Konstruktion dem Katalog von 1718 das Verzeichnis der dem Kloster zu Czerna an der Wende des 19./20. Jahrhunderts von P. Wincenty Smoczyński gespendeten Bücher (Spis ksiag...). 